\title{
USULAN STRATEGI PENGEMBANGAN UKM RUMAH PRODUKSI ANYAMAN BAMBU IBU KARMI DENGAN MENGGUNAKAN METODE SWOT TERINTEGRASI QSPM
}

\author{
Siti Inayah ${ }^{1}$, Deny Andesta ${ }^{2}$, Elly ismiyah ${ }^{3}$ \\ Program Studi Teknik Industri, Fakultas Teknik, Universitas Muhammadiyah Gresik \\ Jl. Sumatera 101 GKB, Gresik 61121, Indonesia \\ e-mail : Sinayah40@gmail.com
}

\begin{abstract}
ABSTRAK
UKM Rumah Produksi Anyaman Bambu Ibu Karmi merupakan salah satu industri rumahan yang memproduksi hasil kerajinan tangan dengan bahan baku bambu. UKM ini terletak di Desa Kumpulrejo Kecamatan Parengan Kabupaten Tuban. Pada bulan januari 2020 - bulan maret 2021 UKM ini telah mengalami penurunan produksi dan penjualan produk. Hal tersebut dipengaruhi oleh Banyak munculnya pesaing baru dengan hasil produk yang sama, terutama pada saat Pandemi Covid 19 yang saat ini terjadi. Yang melatarbelakangi munculnya pesaing baru karena Banyaknya PHK besar-besaran yang ada di kota, sehingga ada beberapa tenaga kerja yang memutuskan pulang kampung dan beralih profesi sebagai pengrajin anyaman bambu sehingga Sumber daya bahan baku yang semakin berkurang karena banyaknya bambu yang dipotong. Selain itu, UKM ini Hanya menerapkan strategi penjualan secara offline ataupun door to door. Penelitian ini bertujuan untuk menentukan Alternatif strategi pengembangan yang harus dilakukan UKM Rumah Produksi Anyaman Bambu Ibu Karmi untuk meningkatkan penjualan. Analisis dari penelitian ini menggunakan data kuantitatif yang didapat dari hasil kuisioner kepada responden yaitu pemilik UKM, 3 karyawan dan 6 konsumen. Metode yang digunakan dalam analis data adalah metode SWOT terintegrasi QSPM. Penelitian ini menghasilkan sebuah 3 Alternatif strategi pengembangan yang dapat diterapkan pada UKM Rumah Produksi Anyaman Bambu Ibu Karmi karena memiliki nilai TAS terbaik diantaramya Melakukan penjualan produk atau promosi melalui media sosial yang berbasis internet dengan nilai TAS 0.816, Melakukan pengembangan serta peningkatan kualitas produk baru dengan cara melakukan inovasi produk yang lebih menarik dengan memanfaatkan SDM yang terampil dengan nilai TAS 0.661 dan Meningkatkan kualitas produk disertai dengan diskon yang menarik dengan nilai TAS 0.661.
\end{abstract}

Kata kunci: Strategi Pengembangan, SWOT, QSPM

\begin{abstract}
Ms. Karmi's SME Bamboo Woven Production House is one of the cottage industries that produces handicrafts using bamboo as raw materials. This UKM is located in Kumpulrejo Village, Parengan District, Tuban Regency. In January 2020 - March 2021, these SMEs have experienced a decline in product production and sales. This is influenced by the emergence of many new competitors with the same product results, especially during the Covid 19 pandemic that is currently happening. The background for the emergence of new competitors is due to the large number of massive layoffs in the city, so that there are some workers who decide to return home and switch professions as woven bamboo craftsmen so that raw material resources are decreasing due to the large number of cut bamboo. In addition, these SMEs only apply offline or door to door sales strategies. This study aims to determine the alternative development strategy that must be carried out by the SMEs of Ibu Karmi's Bamboo Weaving Production House to increase sales. The analysis of this study uses quantitative data obtained from the results of questionnaires to respondents, namely SME owners, 3 employees and 6 consumers. The method used in the data analysis is the QSPM integrated SWOT method. This study resulted in 3 alternative development strategies that can be applied to the SME of Ibu Karmi's Bamboo Weaving Production House because it has the best TAS value among them. Selling products or promotions through internet-based social media with a TAS value of 0.816, Developing and improving the quality of new products by means of make product innovations that are more attractive by utilizing skilled human resources with a value of TAS 0.661 and Improving product quality accompanied by attractive discounts with a value of TAS 0.661.
\end{abstract}

Keywords: Strategy Development, SWOT, QSPM 


\section{Jejak Artikel}

Upload artikel : 15 Desember 2021

Revisi : 25 Desember 2021

Publish : 31 Januari 2022

\section{PENDAHULUAN}

UKM (Usaha Kecil Menengah) adalah suatu bisnis yang dijalankan dengan skala kecil dan menengah, bukan anak atau cabang perusahaan manapun. UKM dijadikan sebagai tumpuan perekonomian karena mampu menyumbang 60\% dari Produk Domestik Bruto (Sidin.C,.dan Miralda. I., 2020).

Kegiatan bisnis yang dilakukan oleh UKM dapat memberikan akomodasi bagi masyarakat dalam memenuhi setiap kebutuhan dan keinginan mereka. Dalam persaingan dunia bisnis yang tak terhindarkan yang diiringi perkembangan teknologi yang semakin modern, ditambah munculnya pandemi virus corona (Covid 19) yang kini telah menyebar ke seluruh dunia, khususnya di Indonesia Provinsi Jawa Timur Tidak sedikit orang yang kehilangan pekerjaan, oleh karena itu, tidak sedikit pula orang yang memutar otak untuk beralih profesi sebagai pelaku UKM. Pertumbuhan UKM di Jawa Timur tumbuh pesat dalam periode terakhir, terutama pada saat pandemic covid 19. Berdasarkan Data Dinas Koperasi dan UKM Jawa Timur, yang merujuk pada data BPS, di Jatim lebih dari 414.000 UKM tumbuh dan keberadaan UKM tersebut berkontribusi 57,52 persen terhadap Produk Domestik Bruto Jawa Timur (Khuriyatul,2021). Dengan adanya persaingan bisnis menuntut pelaku UKM untuk lebih mengembangkan strategi agar dapat memenangkan persaingan dalam merebut pasar domestik. Sama halnya dengan UKM Rumah Produksi Anyaman Bambu Ibu Karmi.

Rumah Produksi Anyaman Bambu Ibu Karmi adalah salah satu UKM yang memproduksi atau menyalurkan hasil kerajinan anyaman bambu yang terletak di Dusun Rembun RT.06 RW.05 Desa Kumpulrejo Kecamatan Parengan Kabupaten Tuban. Industri rumahan ini berdiri sejak tahun 1980 yang didirikan oleh Ibu Karmi. UKM ini menghasilkan berbagai kerajinan tangan, misalnya, Bojog, Kukusan, Tampir, Kalo, Tompo, dan Kipas.

Pembuatan kerajinan Anyaman Bambu ini membutuhkan keterampilan dan keuletan, tetapi bagi penduduk Dusun Rembun keterampilan seperti ini tidak memerlukan pendidikan khusus karena sudah dipelajari secara turun menurun. Kerajinan ini sudah menjadi ciri khas Desa Kumpulrejo sebagai penghasil kerajinan anyaman dari bambu. UKM Rumah Produksi Anyaman Bambu Ibu Karmi tidak hanya menjualkan produknya secara langsung kepada konsumen, tetapi juga menjualkan produk anyaman kepada distributor yaitu ibu Parniti, dengan sasaran penjualan di sekitar kecamatan parengan, kecamatan singgahan, kecamatan senori dan di kecamatan Jatirogo kabupaten Tuban.

Berdasarkan hasil wawancara yaitu kepada pemilik UKM Rumah Produksi Anyaman Bambu permasalahan yang dihadapi yaitu Banyak munculnya pesaing baru dengan hasil produk yang sama, terutama pada saat Pandemi Covid 19 yang saat ini terjadi.

Latarbelakang munculnya pesaing baru yaitu banyaknya PHK besar-besaran yang ada di kota, sehingga ada beberapa tenaga kerja yang memutuskan pulang kampung dan beralih profesi sebagai pengrajin anyaman bambu. Munculnya pesaing baru berimbas pada sumber daya bahan baku yang semakin berkurang karena banyaknya bambu yang dipotong, sedangkan pertumbuhan bambu samapai layak dijadikan bahan baku cukup lama yaitu sekitar umur 5 tahun yang dilakukan terhadap batang generasi ketiga. Setelah itu, panen dilakukan setiap tahun pada batang bambu generasi keempat, kelima dan seterusnya (Oliver, 2019). Selain itu, Rumah Produksi Anyaman Bambu Ibu Karmi hanya menerapkan strategi penjualan secara offline ataupun door to door. Pasalnya Revolusi industri saat ini yang dikenal dengan istilah industri 4.0 membuka peluang untuk perkembangan strategi penjualan dengan mengintegrasikan dunia online dengan lini produksi diindustri, dimana semua proses produksi berjalan dengan internet sebagai penopang utamanya (Uding.S. 2016). Adanya pesaing baru hasil produksi dan penjualan produk juga yang mengalami penurunan. 
Adapun data peroduksi UKM Rumah Produksi Anyaman Bambu Ibu Karmi seperti dibawah ini.

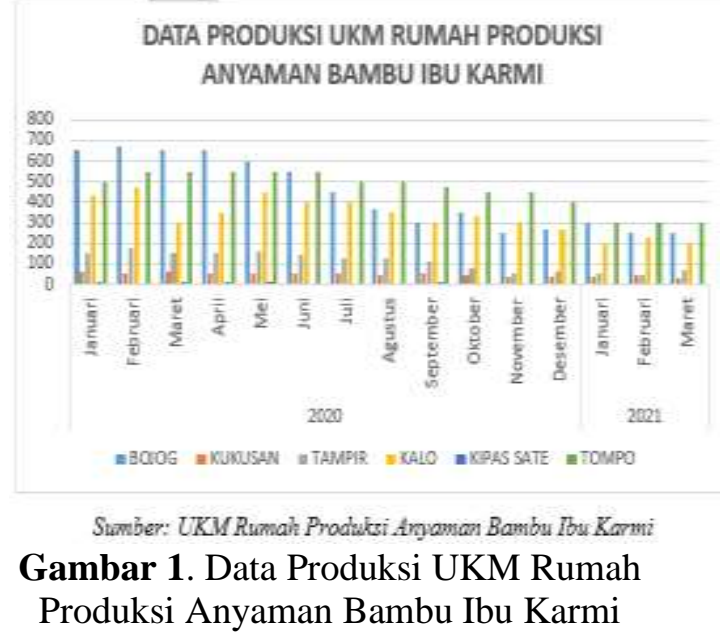

Sesuai dengan wawancara yang dilakukan kepada pemilik UKM bahwa jumlah data penjualan sama dengan data produksi. Karena UKM ini memproduksi anyaman sesuai permintaan. Sehingga pengadaan bahan baku dilakukan saat ada permintaan.

Dari kasus yang dialami oleh UKM Rumah Produksi Anyaman Bambu Ibu Karmi harus mengembangkan berbagai strategi untuk menarik peminat konsumen dalam menghadapi persaingan dengan produsen lainnya. Untuk itu diperlukan strategi perkembangan dengan menggunakan pendekatan SWOT yang disusun berdasarkan analisis lingkungan internal dan lingkungan eksternal yaitu melihat kekuatan dan kelemahan dalam menghadapi peluang dan ancaman baik sekarang maupun masa mendatang. Dari beberapa strategi yang sudah dihasilkan kemudian menentukan alternatif strategi pengembangan yang terbaik untuk UKM Rumah Produksi Anyaman Bambu Ibu Karmi dengan menggunakan metode QSPM. Kelebihan menggunakan Metode QSPM adalah strategistrategi dapat diperiksa secara berurutan dan bersamaan (Hany,S.,dkk. 2016).

Penelitian ini bertujuan untuk Menentukan Alternatif strategi pengembangan yang harus dilakukan UKM Rumah Produksi Anyaman Bambu Ibu Karmi untuk meningkatkan penjualan

\section{METODOLOGI PENELITIAN}

Ada beberapa metode yang dapat digunakan untuk menentukan alternative strategi pengembangan. Salah satu metode yang digunakan dalam penelitian ini adalah metode SWOT yang disusun berdasarkan analisis lingkungan internal dan lingkungan eksternal yaitu melihat kekuatan dan kelemahan dalam menghadapi peluang dan ancaman baik sekarang maupun masa mendatang. Dari beberapa strategi yang sudah dihasilkan kemudian menentukan alternatif strategi pengembangan yang terbaik untuk UKM Rumah Produksi Anyaman Bambu Ibu Karmi dengan menggunakan metode QSPM.

Langkah-langkah dalam menetukan alternative strategi pengembangan adalah sebagai berikut.

\section{Analisis SWOT}

SWOT adalah singkatan dari strengths (kekuatan perusahaan), Weaknesses (kelemahan perusahaan), Opportunities (peluang perusahaan), Threats (ancaman perusahaan). Seperti yang ditunjukkan oleh Rangkuti (2015) dalam Ririn Rubianti (2018) SWOT ialah sebuah cara untuk mengidentifikasi bermacam faktor faktor yang secara sistematis dalam perumusan strategi perusahaan.

\section{a. Evaluasi Matriks IFE}

Matriks IFE (Internal Factor Evaluation) Merupakan bentuk formulasi dari strategi guna mengevaluasi dan meringkas kekuatan dan kelemahan utama. Matriks IFE disusun untuk merumuskan foktor-faktor internal yaitu strength and weaknes perusahaan. Adapun tahapan dalam penentuan nilai strategi internal menurut Rangkuti (2013) dalam Cyrilla, I,P,. (2021):

1. Menentukan faktor yang dijadikan kekuatan dan kelemahan perusahaan.

2. Memberikan bobot pada masing-masing faktor dengan skala mulai dari 1,0 (paling penting) sampai dengan 0,0 (tidak penting). Perlu diingat bahwa seluruh bobot harus jumlahnya tidak boleh melebihi nilai skor total 1,0 .

3. Hitung rating untuk tiap faktor dengan cara memberikan skala 4 sampai 1 , sesuai dengan pengaruh faktor tersebut terhadap keadaan perusahaan yang dinilai.

4. Mengkalikan bobot dengan rating, guna mendapatkan besarnya pembobotan. Hasil akhir berupa nilai skor pembobotan pada masing-masing faktor dengan nilai yang bervariasi dimulai dari 4,0 nilai tertinggi sampai dengan 1,0 nilai terendah yang rataratanya sebesar 2,5. Total rata - rata tertimbang jika dibawah 2,5 maka menggambarkan perusahaan yang lemah secara internal, sedangkan total nilai di atas 
2,5 mengindikasikan bahwa posisi internalnya kuat.

5. Jumlah skor nilai pembobotan, menunjukkan total skor pembobotan pada perusahaan tersebut. Ini memberikan informasi bahwa perusahaan kompetitor bereaksi dengan adanya faktor strategi internalnya. Nilai ini bisa dipakai untuk membandingkan antar perusahaan dalam bidang yang sama

\section{b. Evaluasi Matriks EFE}

Menurut Cyrilla, I,P,. (2021) Matriks EFE (Eksternal Factor Evaluation) disusun untuk merumuskan foktor faktor strategi peluang dan acaman (opportunity and threat). Dengan cara mengevaluasi dan meringkas informasi yang diperoleh dari kekuatan eksternal yang dibagi dalam 5 kategori kekuatan kompetitif, kekuatan ekonomi, kekuatan politik, kekuatan sosial budaya, kekuatan teknologi. Lima langkah menentukan faktor strategi eksternal:

1. Menyusun faktor ekternal yang terdiri dari peluang dan ancaman dalam suatu kolom.

2. Memberi bobot untuk masing-masing factor antara 0 sampai 1 . Nilai satu artinya sangat penting sedangkan nilai 0 tidak penting.

3. Memberikan rangking antara 1 sampai 4 sesuai dengan kondisi perusahaan saat itu, dimana (skor= 1) sedikit penting (skor=2) agak penting, $($ skor $=3)$ penting dan $($ skor $=4)$ sangat penting.

4. Langkah berikutnya mengalikan masingmasing bobot dengan peringkat yang diperoleh supaya rata-rata tertimbang dapat ditentukan.

5. Menjumlahkan rata-rata tertimbang guna mendapatkan total nilai atau skor dari pembobotan perusahaan tersebut. Nilai yang diperoleh dimanfaatkan untuk membandingkan dengan nilai perusahaan kompetitor dengan kelompok yang sejenis.

c. Analisis Matriks IE

Matriks IE digunakan untuk merumuskan strategi dengan melihat posisi perusahaan dalam matriks. Matriks ini menggunakan skor total pembobotan IFE dan skor total pembobotan EFE. Dalam menentukan Matriks IE terdapat dua cara yang pertama, menggunakan diagram kartesius IV kuadran yaitu: kuadran I (Agresif) dengan nilai positif $(+,+)$, kuadran II dengan nilai positif-negatif $(+,-)$, kuadran III dengan nilai negative-positif $(-,+)$, dan kuadran IV dengan nilai negatif-negatif (-,-) (Abiddin, Dkk 2017).
Sedangkan yang kedua yaitu gabungan kedua matriks yang menghasilkan matriks IE yang berisi sembilan sel dengan ketentuan sebagai berikut (Ariza, Q, 2020):

1. Sel I, II, dan IV menggambarkan keadaan perusahaan sebagai growth and build (kembang dan bangun). Untuk itu, Strategi yang cocok untuk diterapkannya yaitu intensif yang meliputi penetrasi pasar, pengembangan pasar, dan pengembangan produk atau strategi integrasi yang meliputi integrasi ke depan, integrasi ke belakang dan integrasi horizontal.

2. Sel III, V, dan VII menggambarkan keadaan perusahaan sebagai hold dan maintain atau pertahankan dan pelihara. Strategi yang biasa digunakan yaitu penetrasi pasar dan pengembangan produk.

3. Sel VI, VIII, dan IX menggambarkan keadaan perusahaan sebagai harvest or divest (mengambil hasil atau melepaskan). Strategi yang biasa dilakukan adalah divestasi strategi, diversifikasi konglomerat, dan melakukan likuidasi. Posisi perusahaan pada sel ini dapat digunakan untuk menentukan perumusan alternatif strategi yang sesuai. Selanjutnya, hasil dari matriks ini dapat dijadikan acuan dalam merumuskan strategi pada matriks SWOT dengan mengkombinasikan faktor kekuatan, kelemahan, peluang dan ancaman yang berkaitan.

4.

\section{d. Analisis Matriks SWOT}

Menurut Ariza, Q..(2020) Ada empat macam strategi yang dapat dikembangkan dengan matriks SWOT, yaitu sebagai berikut:

1. Strategi Strength-Opportunity (SO)

Strategi Strength -Opportunity dapat digunakan untuk memaksimalkan kekuatan internal perusahaan dalam memanfaatkan peluang yang ada.

2. Strategi Weakness-Opportunity (WO)

Strategi Weakness -Opportunity dapat digunakan untuk meminimalisir kelemahan dengan memanfaatkan peluang yang ada.

3. Strategi Strength-Threat (ST)

Strategi Strength -Threat dapat digunakan untuk mengurangi ancaman dari luar perusahaan dengan memaksimalkan kekuatan yang telah dimiliki.

4. Strategi Weakness-Threat (WT)

Strategi Weakness -Threat bersifat defensive dan dapat digunakan untuk mengurangi kelemahan yang dimiliki dan 
menghindari munculnya ancaman dari luar perusahaan.

\section{Analisis Matriks QSPM}

Seperti yang ditunjukkan oleh Ariza, Q.,(2020) Matriks QSPM (Quantitative Strategic Planning Matrix) adalah matriks yang digunakan untuk menganalisis berbagai strategi yang tersedia untuk mendapatkan alternative strategi yang terbaik dan yang diprioritaskan. Alternatif strategi yang dianalisis pada tahap ini yaitu strategi yang sudah dihasilkan dalam perumusan strategi melalui Matriks SWOT. Pada perhitungan QSPM terdapat beberapa strategi yang sudah dihasilkan dari matriks SWOT, kemudian nilai bobot diperoleh dari hasil kuisioner oleh responden serta nilai AS (Attractiveness Scores) yang ditentukan dengan mengevaluasi masing-masing strategi. Secara khusus, Nilai Daya Tarik diberikan untuk masing-masing strategi untuk menunjukan daya tarik keseluruhan dari satu strategi atas strategi lainnya, dengan mempertimbangkan variabel tertentu. Jangkauan skor Nilai Daya Tarik adalah 1 = Tidak Menarik, 2 = Agak Menarik, $3=$ Cukup Menarik, 4 = Sangat Menarik, Sementara nilai TAS (Total Attractiveness Scores) didapatkan dari hasil pengalian nilai Bobot dan nilai AS (Attractiveness Scores).

Nilai TAS diperoleh dengan mengkalikan bobot dengan nilai AS. Skor tertinggi menentukan alternative strategi yang terbaik untuk diterapkan dalam suatu perusahaan. Contoh Matriks QSPM dapat dilihat pada tabel 1.

Tabel 1 Contoh Matriks QSPM

\begin{tabular}{|l|l|l|l|l|}
\hline No. & Strategi & Bobot & AS & TAS \\
\hline $\mathbf{1}$ & Strategi 1 & & & \\
\hline $\mathbf{2}$ & Strategi 2 & & & \\
\hline $\mathbf{3}$ & Strategi 3 & & & \\
\hline $\mathbf{4}$ & Strategi 4 & & & \\
\hline $\mathbf{5}$ & Strategi 5 & & & \\
\hline
\end{tabular}

(Sumber: Peneliti, 2021)

\section{HASIL DAN PEMBAHASAN}

\subsection{Tahap Input}

Pada tahapan ini, dilakukan penilaian untuk menentukan bobotan dan rating untuk faktor internal yang akan menjadi kekuaatan dan kelemahan perusahaan dan juga faktor eksternal yang akan menjadi peluang serta ancaman bagi UKM Rumah Produksi Anyaman Bambu Ibu Karmi. Hasil pengolahan data menggunakan matrik EFE dan juga matriks IFE, seperti tabel 2. Nilai skor diperoleh dari mengalikan nilai bobot serta rating setiap responden yang diperoleh dari faktor internal yang diprioritaskan. Kekuatan yang paling besar dimiliki pihak UKM dari faktor internal pada Matriks IFE adalah Keuangan dan tempat usaha milik sendiri dengan nilai skor 0.508 dan kelemahan paling utama penjualan secara offline dengan nilai skor 0.220 .

Tabel 2 Hasil Matriks IFE

\begin{tabular}{|c|c|c|c|c|}
\hline No. & $\begin{array}{l}\text { Faktor- } \\
\text { faktor }\end{array}$ & \multirow{2}{*}{$\begin{array}{l}\text { Bobo } \\
\text { t }\end{array}$} & \multirow{2}{*}{$\begin{array}{l}\text { Peri } \\
\text { ngka } \\
\text { t }\end{array}$} & \multirow{2}{*}{$\begin{array}{l}\text { Skor } \\
\text { Bobot }\end{array}$} \\
\hline \multicolumn{2}{|c|}{ Kekuatan } & & & \\
\hline 1 & $\begin{array}{l}\text { Bambu yang } \\
\text { sudah tua } \\
\text { atau pilihan }\end{array}$ & 0.126 & 3.6 & 0.456 \\
\hline 2 & $\begin{array}{l}\text { Keuangan } \\
\text { dan tempat } \\
\text { usaha milik } \\
\text { sendiri }\end{array}$ & 0.133 & 3.8 & 0.508 \\
\hline 3 & $\begin{array}{l}\text { Sumber Daya } \\
\text { Manusia } \\
\text { yang terampil }\end{array}$ & 0.126 & 3.6 & 0.456 \\
\hline 4 & $\begin{array}{l}\text { Karyawanny } \\
\text { a ramah }\end{array}$ & 0.112 & 3.2 & 0.360 \\
\hline 5 & $\begin{array}{l}\text { Harga yang } \\
\text { ditawarkan } \\
\text { dapat } \\
\text { dijangkau }\end{array}$ & 0.126 & 3.6 & 0.456 \\
\hline \multicolumn{5}{|c|}{ Kelemahan } \\
\hline 1 & $\begin{array}{l}\text { penjualan } \\
\text { secara offline }\end{array}$ & 0.088 & 2.5 & 0.220 \\
\hline 2 & $\begin{array}{l}\text { Peralatan } \\
\text { masih } \\
\text { tradisional }\end{array}$ & 0.066 & 1.9 & 0.127 \\
\hline 3 & $\begin{array}{l}\text { Minimnya } \\
\text { laba } \\
\text { penjualan } \\
\text { produk }\end{array}$ & 0.073 & 2.1 & 0.155 \\
\hline 4 & $\begin{array}{l}\text { Belum } \\
\text { memiliki ijin } \\
\text { usaha }\end{array}$ & 0.070 & 2 & 0.140 \\
\hline 5 & $\begin{array}{l}\text { Produk } \\
\text { mudah ditiru }\end{array}$ & 0.073 & 2.1 & 0.155 \\
\hline \multicolumn{4}{|c|}{ Total } & 3.036 \\
\hline
\end{tabular}

Matriks EFE hampir sama langkahlangkanya dengan Matriks IFE. Namun faktor 
strategi yang digunakan berbeda, dimana Matriks EFE menggunakan faktor strategi berupa Ancaman dan Peluang UKM. Sedangkan untuk faktor strategi yang digunakan untuk Matriks IFE berupa kekuatan dan kelemahan UKM. tabel 3 menunjukan hasil perhitungan Matriks EFE

Tabel 3 Matriks EFE

\begin{tabular}{|c|l|l|l|l|}
\hline $\begin{array}{l}\text { N } \\
\text { o }\end{array}$ & Faktor-faktor & Bobot & $\begin{array}{l}\text { Peri } \\
\text { ngka } \\
\text { t }\end{array}$ & $\begin{array}{l}\text { Skor } \\
\text { Bobot }\end{array}$ \\
\hline \multicolumn{1}{|c|}{ Peluang } & $\begin{array}{l}\text { Tersedianya penjualan } \\
\text { produk berbasis } \\
\text { internet }\end{array}$ & 0.145 & 4 & 0.583 \\
\hline 2 & Inovasi produk. & 0.127 & 3.5 & 0.447 \\
\hline 3 & $\begin{array}{l}\text { Ketersediaan bahan } \\
\text { baku tetap melimpah }\end{array}$ & 0.131 & 3.6 & 0.472 \\
\hline 4 & $\begin{array}{l}\text { Perkembangan } \\
\text { teknologi produksi }\end{array}$ & 0.127 & 3.5 & 0.447 \\
\hline 5 & $\begin{array}{l}\text { Adanya dukungan dari } \\
\text { pemerintah }\end{array}$ & 0.131 & 3.6 & 0.472 \\
\hline Ancaman tan & $\begin{array}{l}\text { Beralihnya pelanggan } \\
\text { kepesaing sejenis }\end{array}$ & 0.083 & 2.3 & 0.193 \\
\hline 2 & $\begin{array}{l}\text { Adanya } \\
\text { perkembangan } \\
\text { teknologi yang sangat } \\
\text { pesat }\end{array}$ & 0.072 & 2 & 0.145 \\
\hline 3 & $\begin{array}{l}\text { Harga produk pesaing } \\
\text { lebih murah }\end{array}$ & 0.065 & 1.8 & 0.118 \\
\hline 4 & $\begin{array}{l}\text { Peningkatan peraturan } \\
\text { pemerintah tentang } \\
\text { ijin usaha }\end{array}$ & 0.058 & 1.6 & 0.093 \\
\hline 5 & $\begin{array}{l}\text { Ketersediaan bahan } \\
\text { baku habis }\end{array}$ & 0.054 & 1.5 & 0.082 \\
\hline Total & & 3.056 \\
\hline
\end{tabular}

Cara mencari nilai skor bobot dari faktor eksternal diperoleh dari nilai bobot dikalikan dengan nilai peringkat. Contoh faktor nomor 1 dari faktor peluang Tersedianya penjualan produk berbasis internet yaitu $0.145 \times 4=0.583$. Sehingga dari perhitungan diatas maka hasil Matriks IFE sebesar 3.056 atau 3.0.

\subsection{Tahap Pencocokan}

Pada tahap ini dilakukan pencocokan agar diketahui posisi UKM saat ini, supaya strategi alternatif dapat segera diperoleh yang berdasar factor internal dan eksternal. Untuk matrik IE diperoleh berdasarkan dari hasil perhitungan yang dilakukan diatas dengan nilai total skor pada matrik EFE dan IFE. Nilai total IFE $+1,439$, nilai total ini menunjukan nilai pada sumbu $\mathrm{X}$. sementara nilai pada sumbu Y sebesar $+1,791$, sehingga posisi UKM Rumah Produksi
Anyaman Bambu Ibu Karmi pada koordinat $(+1,439 ;+1,791)$

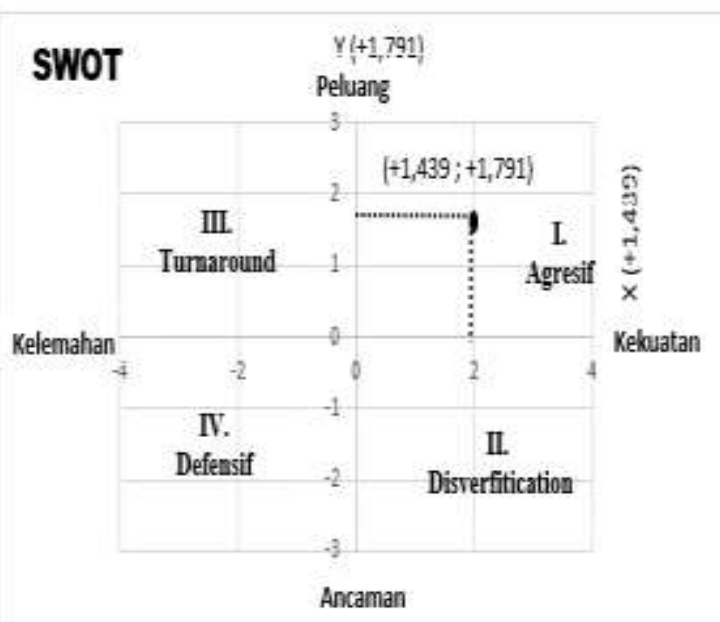

Gambar 2 Kuadrat SWOT

Sementara Berdasarkan Matriks IFE yang menunjukkan bahwa UKM berada pada posisi kuat dengan total skor bobot 3.0 dan untuk Matriks EFE UKM Rumah Produksi Anyaman Bambu berada diposisi kuat juga dengan hasil total skor sebesar 3,0 jika nilai skor bobot faktor internal dan eksternal di petakan kedalam Matriks IE maka posisi UKM berada diposisi sel ke-1 diamana pada sel I ini termasuk dalam kategori strategi Growth and Build (berkembang dan bangun) artinya strategi pertumbuhan perusahaan itu sendiri. Dimana strategi yang umum di terapkan adalah strategi intensif (penetrasi pasar, pengembangan produk) atau strategi intregatif (intregasi kebelakang, kedepan, dan horizontal). Dapat dilihat pada tabel 4 dibawah ini.

Tabel 4 Matriks IE

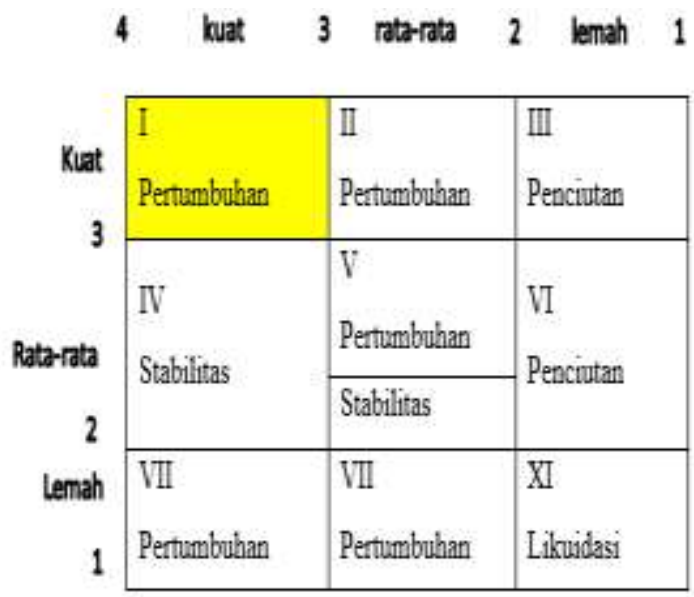

Perumusan strategi dengan matriks SWOT dibuat berdasarkan hasil dari analisis 
sebelumnya yaitu matrik IE dapat dilihat pada tabel 4.8. Dalam Mariks IE diketahui bahwa UKM Rumah Produksi Anyaman Bambu Ibu Karmi berada pada kuadran I diamana pada sel I ini termasuk dalam kategori strategi Growth and Build (berkembang dan bangun) artinya strategi pertumbuhan perusahaan itu sendiri dan strategi yang pada umumnya diterapkan adalah strategi intensif (penetrasi pasar, pengembangan produk) atau strategi intregatif (intregasi kebelakang, kedepan, dan horizontal). Tujuan dilakukannya matriks SWOT ini ialah untuk mengumpulkan hasil dari beberapa strategi yang akan digunakan oleh UKM Rumah Produksi Anyaman Bambu Ibu Karmi. Sebagai pertimbangan dalam merumuskan strategi dengan melakukan brainstorming yaitu melakukan wawancara dan diskusi kepada pemilik UKM Rumah Produksi Anyaman Bambu Ibu Karmi dan kepada pihakpihak terkait seperti karyawan.

Tabel 5 Hasil Matriks SWOT

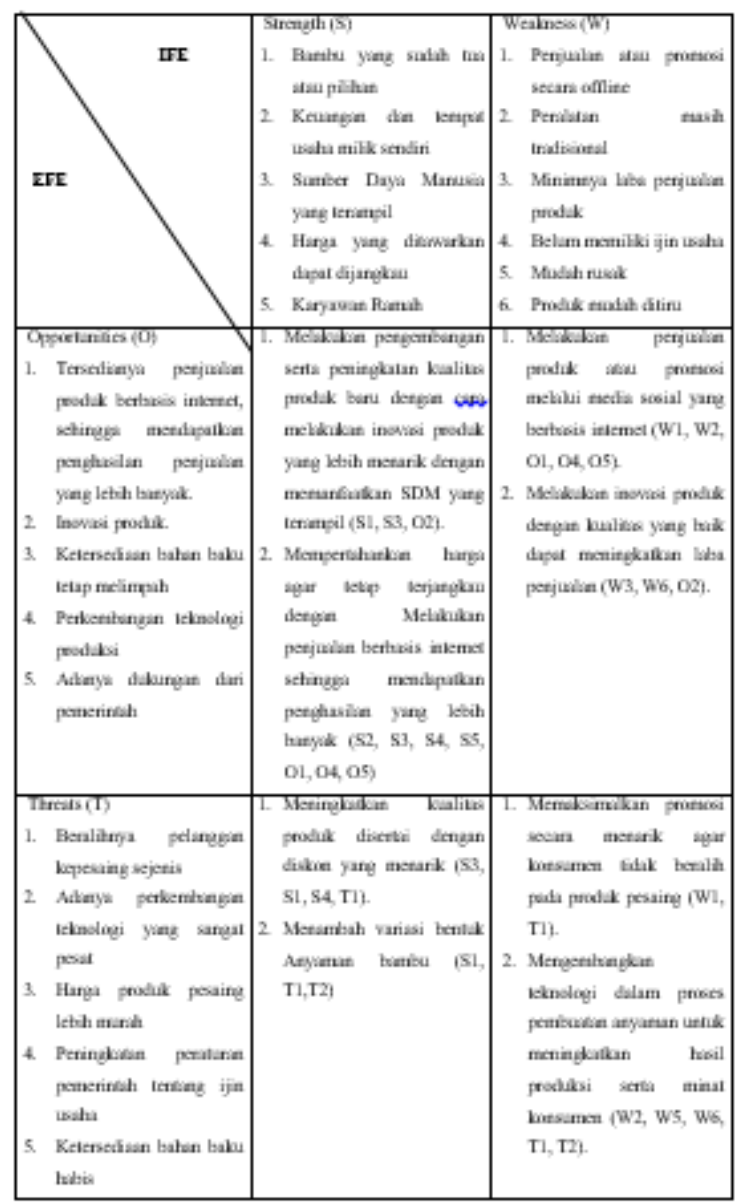

Berdasarkan Matrik SWOT diatas dapat dirumuskan beberapa alternative strategi yang dihasilkan yaitu:

\section{Strategi SO}

Strategi SO atau strategi kekuatan peluang adalah strategi yang dimiliki UKM untuk memanfaatkan peluang yang ada. Adapun strateginya adalah sebagai berikut:

a. Melakukan pengembangan serta peningkatan kualitas produk baru dengan cara melakukan inovasi produk yang lebih menarik dengan memanfaatkan SDM yang terampil (S1, S3, $\mathrm{O} 2$ ).

b. Mempertahankan harga agar tetap terjangkau dengan Melakukan penjualan berbasis internet sehingga mendapatkan penghasilan yang lebih banyak (S2, S3, S4, S5, O1, O4, O5).

2. Strategi WO

Strategi WO atau strategi kelemahan peluang adalah strategi yang memanfaatkan peluang untuk memperkecil kelemahan yang dimiliki oleh UKM. Adapun strateginya adalah sebagai berikut: 
a. Melakukan penjualan produk atau promosi melalui media sosial yang berbasis internet (W1, W2, O1, O4, O5).

b. Melakukan inovasi produk dengan kualitas yang baik dapat meningkatkan laba penjualan (W3, W6, O2).

3. Strategi ST

Strategi ST atau strategi kekuatan ancaman adalah strategi yang memanfaatkan kekuatan untuk menghadapi ancaman yang ada. Adapun strateginya sebagai berikut:

a. Meningkatkan kualitas produk disertai dengan diskon yang menarik (S3, S1, T1).

b. Menambah variasi bentuk Anyaman bambu $(\mathrm{S} 1, \mathrm{~T} 1, \mathrm{~T} 2)$

4. Strategi WT

Strategi WT atau strategi kelemahan ancaman adalah strategi yang meminimalkan kelemahan untuk menghindari ancaman pada UKM. Adapun strateginya adalah sebagai berikut:

a. Memaksimalkan promosi secara menarik agar konsumen tidak beralih pada produk pesaing (W1, T1).

b. Mengembangkan teknologi dalam proses pembuatan anyaman untuk meningkatkan hasil produksi serta minat konsumen (W2, W5, W6, T1, T2).

\subsection{Tahap Keputusan}

Melalui pendekatan analisis QSPM strategi alternatif yang terbaik akan dipilih. Pada perhitungan QSPM terdapat beberapa strategi yang sudah dihasilkan dari matriks SWOT, kemudian nilai bobot diperoleh dari hasil kuisioner oleh 10 responden yaitu pemilik UKM, 3 Karyawan dan 6 konsumen

Tabel 6 Hasil Matriks QSPM

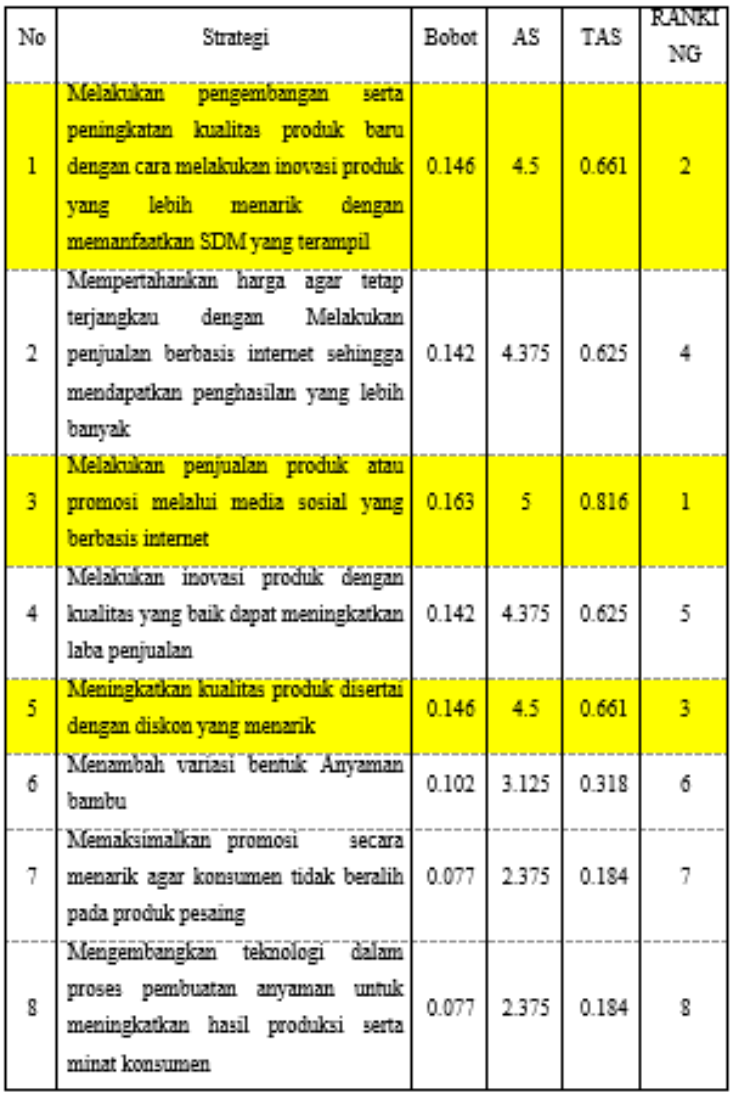

Pada tabel 6 menunjukkan bahwa alternative strategi pengembangan dengan nilai terbayak terdapat pada pertama, strategi melakukan penjualan produk atau promosi melalui media sosial yang berbasis internet dengan nilai Bobot sebesar 0.1633, sedangkan nilai AS sebesar 5 dan nilai TAS sebesar 0.8163 . Kedua, Melakukan pengembangan serta peningkatan kualitas produk baru dengan cara melakukan inovasi produk yang lebih menarik dengan memanfaatkan SDM yang terampil dengan nilai Bobot sebesar 0.1469, sedangkan nilai AS sebesar 4,5 dan nilai TAS sebesar 0.6612. ketiga, Meningkatkan kualitas produk disertai dengan diskon yang menarik dengan nilai Bobot sebesar 0.1469, sedangkan nilai AS sebesar 4,5 dan nilai TAS sebesar 0.6612 .

\section{KESIMPULAN}

Terdapat 3 Alternatif strategi pengembangan yang dapat diterapkan pada UKM Rumah Produksi Anyaman Bambu Ibu Karmi karena memiliki nilai TAS terbaik diantaramya Melakukan penjualan produk atau promosi melalui media sosial yang berbasis internet dengan nilai TAS 0.816, Melakukan pengembangan serta peningkatan kualitas produk baru dengan cara melakukan inovasi produk yang lebih menarik dengan memanfaatkan SDM yang terampil dengan nilai 
TAS 0.661 dan Meningkatkan kualitas produk disertai dengan diskon yang menarik dengan nilai TAS 0.661 .

\section{DAFTAR PUSTAKA}

Abiddin, Dkk. (2017). Pemilihan Strategi Pemasaran Dengan Metode SWOT Dan TOPSIS. Jurnal Teknik Industri. Vol. 18, No. 01

Arief Rahmana, Dkk. (2012). Strategi Pengembangan Usaha Kecil Menengah Sektor Industri Pengolahan. Jurnal Teknik Industri, Vol. 13, No. 1

Ariza Q. (2020). Analisis Strategi Dengan Metode Swot Dan Qspm (Quantitative Strategic Planning Matrix): Studi Kasus Pada D'gruz Caffe Di Kecamatan Bluto Sumenep. Jurnal Ilmiah Manajeme. Vol. 1 No. 2.

Cyrilla, I, P,. (2021). Strategi Mengembangkan Bisnis Saat Pandemi Cofid-19 Menggunakan Metode Swot Dan Qspm (Studi Kasus Supermarket Abc). Gaung Informatika. V (14), No.1.

Daru.A.Dewantoro. (2021). Perumusan Strategi Rekomendasi UKM Pada Masa Pandemi Covid-19 (Studi kasus: UD Darmaji). Performa: Media Ilmiah Teknik Industri Vol. 20, No. 1

Elisabet, L., DKK. (2021). ANALISIS STRATEGI BERSAING UMKM MENGGUNAKAN FORMULASI MATRIKS MANAJEMEN STRATEGIS. JURNAL MANAJEMEN BISNIS. Vol.17 (2 ) : $101-115$

Fauzi. S. Y,. (2018). Analisis Perancangan Strategi Dengan Pendekatan Blue Ocean Strategy Untuk Meningkatkan Penjualan Dalam Persaingan Bisnis (Studi Kasus Di 10 Semester Coffee Shop). Skripsi, Universitas Islam Indonesia Yogyakarta. Yogyakarta.

Fuadi.A. (2019). Strategi Pengembangan Sentra Batik Jetis Sidoarjo Menggunakan Swot, Space Dan Qspm. Jurnal Prosiding Semnas, Vol. 1

Hany.S.,Dkk. (2016). Analisis Strategi Pemasaran Menggunakan Matriks SWOT Dan QSPM (Studi Kasus:
Restoran WS Soekarno Hatta Malang). Jurnal Teknologi Dan Manajemen Agroindustri 5(1): 46-53.

Harmaizar.Z. (2008). Menangkap Peluang Usaha Edisi Kedua. Penerbit Gramedia, Bekasi.

Hasnawiah. (2020). Perilaku Pengusaha Ternak Ayam Petelur Di Polewali Kabupaten Pinrang (Tinjauan Etika Bisnis Islam). Skripsi. Institut Agama Islam Negeri (Iain) Parepare.

Khuriyatul. (2020). Peran UMKM Dalam Mempertahankan Ekonomi Jawa Timur Selama Pandemic COVID-19. Mojokerto.

Meftahudin,. Dkk. (2018). Penerapan Analisis SWOT dan Five Forces Porter Sebagai Landasan untuk Merumuskan Strategi Pemasaran dalam Meningkatkan Laba Perusahaan (Studi Pada Tin Panda Collection di Kabupaten Magelang). Journal of Economic, Management, Accounting and Technology (JEMATech). Vol. 1, No. 1

Rangkuti, Freddy. (1997). Analisis SWOT Teknik Membedah Kasus Bisnis. Jakarta PT. Gramedia Pustaka Utama.

Rachmad. H.Alif, Deny Andesta dan Said Salim Dahda. (2020). Pendekatan Metode Analisis Swot Matriks Ife \& Efe Dan Analitycal Hierarchy Process Pada Strategi Pemasaran Ukm Bu Muzana. Justi (Jurnal Sistem Dan Teknik Industri). Vol. 1, No. 4

Ramadona, S,. Dkk. (2020). Strategi Pemasaran Produk Keripik Ud. Bagus Abadi Jaya Menggunakan Metode Swot (Strengths, Weaknesses, Opportunities, Threats) Dan Qspm (Quantitative Strategic Planning Matrix). Justi (Jurnal Sistem Dan Teknik Industri). Vol. 1, No. 4

Ridhanto.M.R, Dan Nilasari.M.A. (2020). Strategi Pengembangan Agribisnis Kedelai Lokal Untuk Meningkatkan Pendapatan Petani Di Kabupaten Lombok Tengah. Jurnal Ilmu-Ilmu Pertanian.

Ririn Rubianti. (2018). Pengembangan Usaha Di Rumah Konveksi Garut (Rkg). Jurnal 
Kalibrasi Sekolah Tinggi Teknologi Garut. Vol.16 No. 2.

Sidin.C, dan Miralda. I. (2020). Pengaruh Jumlah Usaha Mikro Kecil Menengah Dan Jumlah Tenaga Kerja Umkm Terhadap Sumbangan Produk Domestik Bruto Umkm Periode Tahun 1997 - 2016. Jurnal Manajemen Kewirausahaan Vol. 16 No. 02.

Oliver. (2019). Program Kemitraan masyarakat (PKM) kelompok pengrajin anyaman bambu prima bambu dalam rangka peningkatan aspek produksi, Yokgakarta. Universitas Pembangunan Nasional "Veteran".

Uding.S. (2016). Strategi Pengembangan Bisnis Produk Hortikultura Pada Waaida Farm. Jurnal Sains Terapan Edisi Vi Vol-6 (1): $63-82$ 